درجة القلق الامتحان لدى طابة الخامس الإعدادي في أداء الاختبار (الامتحمان)

م.م صبري عبد الله كاظم ألركابي

مديرية تربية مهافظة ذي قارا وزارة التربية

مفغص بالاغة العربية

هدف البحث التعرّف على درجة القلق النفسي لدى طلبة الخامس الإعدادي في أداء الاختبار الامتحان، وتكونت عينة البحث من ( • (10)

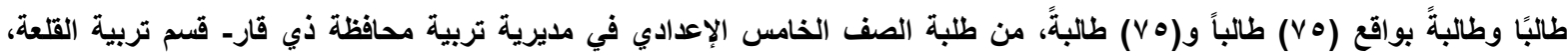
اختيروا بالطريقة الحصر، ونظرًا لطبيعة البحث اعتمد الباحث المنهج الوصفي، ولتحقيق أهداف البحث، تبنى الباحث مقياس القلق(أبوعرب، منه

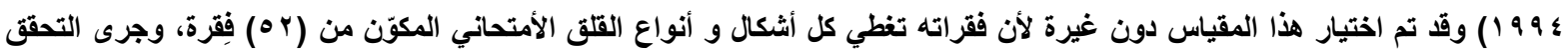
من صدق المقياس وثباته، وأعتمدت حزمة التحليل الإحصائي (spss) لاستخراج النتائج أظهرت النتائج:

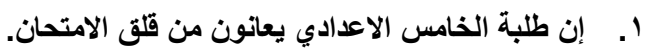

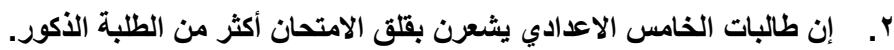
r. إن الطلبة والطالبات من ذوي التخصص العلمي لايهم قلق امتحان أكثر من طلبة وطالبات التخصص الأدبي. وقد أوصى البحث بما يأتي: ا. . علدم تخويف الطلبة أثناء تأديتهم للامتحان بل أشعارهم بالتقبل والمودة والعلاقة الإنسانية الطيبة وتخفيف الضغوطات النفسية على قرر الإمكان

$$
\begin{aligned}
& \text { ץ. محاولة تغيير الأساليب المتبعة في التعليم من قبل الأساتذة وعدم استخدام التهايد والكف عن التهويل. } \\
& \text { r. تنمية وتعزيز الثقة بالنفس لاى الطلبة بإمكانياتهم والتقلم والنجاح في المستقبل. } \\
& \text { ؛. . الاهتمام بالإعداد النفسي للطلاب واستخدام الاختبارات النفسية كوسيلة موضوعية لتقويم حالة الطلبة. } \\
& \text { المقترحات : في ضوء النتائج التي توصل لها البحث نقدم بعض المقترحات وهي: }
\end{aligned}
$$

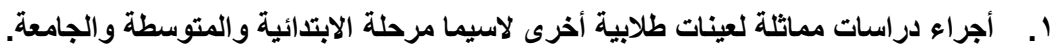

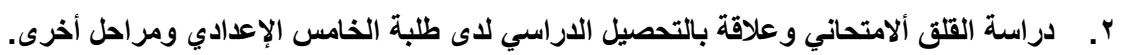

The degree of psychological anxiety among the students of the fifth year in the performance

\title{
of the exam (exam)
}

\section{M Sabri Abdullah Kazem Al Rikabi}

Directorate of Education province of Dhi Qar \Department of Education Qal'at Sukkar

The aim of the research was to identify the degree of psychological anxiety among the students of the fifth year in the performance of the exam. The research sample consisted of 10 . students with vo students and vo students from the fifth grade preparatory school in Dhi Qar Governorate Education Department In order to achieve the objectives of the research, the researcher adopted the measure of anxiety (Abu Arab, 199 ). This measure was chosen without jealousy because its paragraphs cover all forms and types of exam anxiety consisting of (or) The validity and consistency of the scale were verified and the statistical analysis package (SPSS) was adopted for use Production results showed the results:

1. The students of the fifth grade suffer from examination anxiety.

$r$. The students of the fifth preparatory school feel more concerned about the exam than male students. 
r. The students and students of scientific specialization have an examination concern more than students of literary specialization.

The research recommended the following:

1. Not to intimidate the students during the performance of the exam, but to inform them of acceptance and affection and good human relationship and relieve psychological pressure as much as possible.

$r$. Trying to change the methods used in teaching by the professor and not to use the threat and stop exaggeration.

r. Develop and enhance students' self-confidence in their potential, progress and success in the future.

๕. Attention to the psychological preparation of students and the use of psychological tests as an objective means to assess the situation of students.

\section{Proposals}

In the light of the findings of the research, we present some suggestions:

1. Conduct similar studies for other student samples, especially primary, intermediate and university levels.

$r$. Examination of the test anxiety and relation to the academic achievement of the students of the fifth and other stages

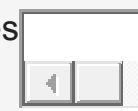

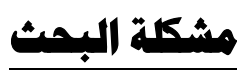

يتعرض الطلبة لمو اقف كثيرة في العملية التعليمية ولكن أكثـــر هاصـعوبة هو أداء الاختبـار أو كما يسمى (الامتحان) لأنه يمثل عملية تقويم مستوى الطالب ومقدار ما تم تحقيقه من نجاح وقد يختلف من طالب إلى أخر حسب الفروق الفردية ولكن توجد بعض العلامـات التي تبين مستوى قلق الطالب من الاختبار هي الارتبالك و الخوف وقد يصـاحب حالة القلق خاصـة استثارة وتغير ات فسيولوجية كارتفاع ضـغط الدم وازديـاد معدل خفقان القلب و التنفس و العرق الغزير وجفاف الفم وارتعاش الأطر اف والثعور بالغثيان، كما تبدي بعض مظـاهر القلق في الثرود الذهني وصعوبة تركيز الانتباه وتدهور المقدرة على التفكير الموضوعي والارتجاف والارتعاد والتحفز و النشـاط الحركي ممـا يؤدي بـالفرد الى الثـعور بالإعياء وسوء التوافق. ومن الملاحظ أن مظـاهر القلق قد تبدو و اضحة على بعض الطلبة عند مواجهة الاختبار (الامتحان) فيدخل هذا القلق مع قدرات أو قدرة الطالب على تذكر المعلومات بشكل جيد مما يحول دون تقديم أداء مناسباً في الاختبار.

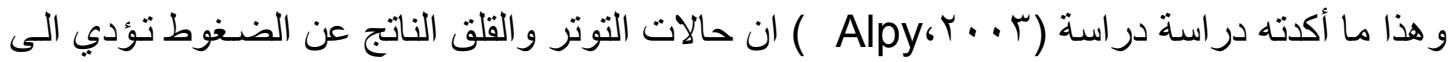
حالة وهن نفسي وجسدي، و هذا ليس جديداً بل منذ القدم ولكن شهد تطورا فإذا بـه يصبح خطر ا أكثر من الماضـي

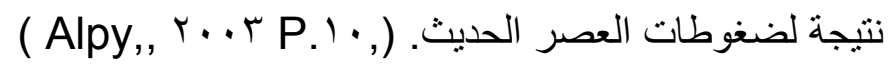
مما سبق يرى الباحث أن من أهم و اعقد المشـاكل التي تواجها الطالب في المرحلة الإعداديـة هي مشكلة قلق الامتحان و على الرغم من اهتمام عدد من الباحثين بمر اجعة الأدب التربوي في مجال القلق بشكل عام، وحسب ـ 
حدود علم الباحثــ لا توجد در اسـات تبين القلق الامتحاني لدى الطلبـة في هذه المرحلة في العراق ، فقد تصدى البحث الر اهن إلى الكثف عن درجة القلق النفسي لدى طلبة الخامس الإعدادي في أداء الاختبار الامتحسان. لذلك فإنَّ البحث الحالي يعد محاولة حقبقية لمعرفة درجة القلق الامتحاني لدى طلبـة الخامس الإعدادي في أداء الاختبار الامتحان بالإجابة عن الأسئلة الآتية:

\section{ا. . ما درجة القلق الامتحاني لدى طلبة الخامس الإعدادي في أداء الاختبار الامتحان؟}

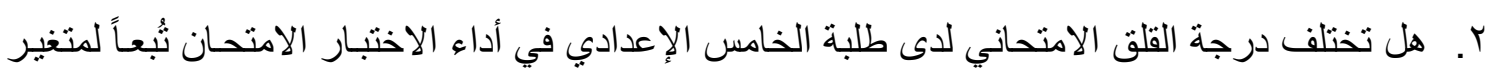

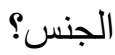

r. هل تختلف درجة القلق الامتحاني لدى طلبة الخامس الإعدادي في أداء الاختبار الامتحسان تبعاً لمتغير

$$
\text { التخصص (علمي - ادبي)؟ }
$$

أهمية البحث: إن ارتفاع حالـة القلق بين الطلبة بصسورة عامـة ينتج عن وجود صـر اع داخلي وحالة انفعالية تعتمد على مستوى استعدادهم للقلق اي مستوى سمة القلق عندهم فالطالب الذي يتسم بـالقلق العالي يستجيب لموقف التهديد بخوف شديد زائد عن الحد العـادي ام المهتم بـالقلق المنخفض فانه يستجيب للتهديد بشكل عـادي وطبيعي. فقد توصل الباحثون في جامعة واشنطن و الذي أبدته البحوث الطبية ان التعرض للتوتر و القلق يزيد من مستويات هرمون الكوتيزول الذي ينتمـي الى هرمونـات القلق التي تعطل توريد الطاقة الى خلايـا الدماغ

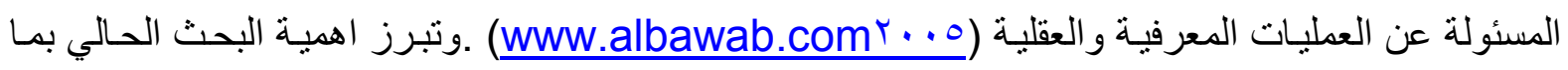

اـ الأهمية النظرية: إذ يمكن الخروج بمجمو عة من التوصيات و المقترحات التي من شأنها الوقوف على مشكلة القلق الامتحاني لطلبة الخامس الإعدادي و إيجاد السبل الكفيلة لتقليل من حدته.

ץ-الأهمية التطبيقية: يمكن الاستفادة من نتائج هذا البحث للوقوف على إبعاد الاضطر ابات النفسية ومنها القلق الامتحاني الذي يؤدي الى سوء التكيف لاى الطلاب وجعلهم في حالة من الثد النفسي و التوتر، و علية فالتعرف على صحة الطلاب النفسية أمر ضروري لأنها في الو اقع تشكل تحدياً لابد من مواجهته بـالطر ائق والأسـاليب

العلمية الصحيحة.

$$
\text { أهداف البحث: يهذف البحث الحالي التعرف على: }
$$

1 - درجة القلق النفسي لدى طلبة الخامس الإعدادي في أداء الاختبار الامتحان؟ r- الفروق بين درجة القلق النفسي لدى طلبة الخامس الإعدادي في أداء الاختبار الامتحان تُبعا لمتغير الجنس. بـ درجة القلق الامتحاني لاى طلبة الخامس الإعدادي في أداء الاختبار الامتحان تبعاً للتغير التخصص (علمي - ادبي) 
حدود البحث ومحدداته: يقتصر البحث الحالي على طلبة الخامس الإعدادي الصف الخامس (العلمي، الادبي)

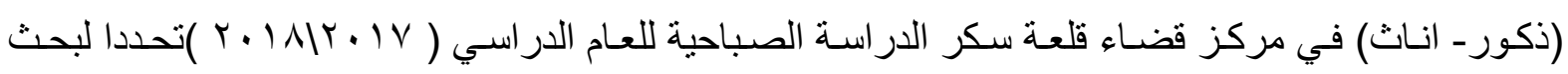
بأداته، وصدقها، وثباتها و النتائج المتحققة منها.

تصديد الإسمات:

أولاً: القلق (Anxiety): عرفـه ألخالدي (9 . . ؟): حالـة انفعالية غير سـارة لدى الفرد نؤثر في مستوى أدائهـ و علاقاته الاجتماعية ومدى شـوره بالطمأنينة نتيجة تعرضـه لمو اقف نفسية ضـاغطة خـلال حياته ـ ـ (الخالدي،

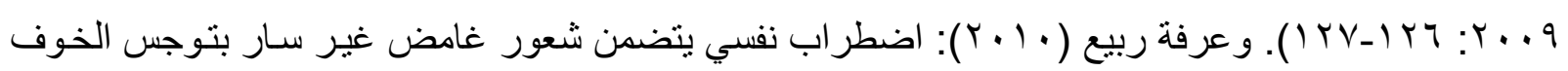

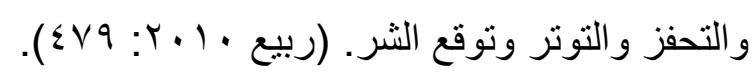

التعريف الإجرائي: هو شعور انفعالي غامض غير سـار يعتري الإنسـان بـالتوجس والخوف والتحفز و التوتر مصـحوب عـادة ببعض الإحساسـات الجسمية مثل الضيق في التنفس أو الثـعور بنبضـات القلب أو الصـداع ويصاحبها نشاط في الجهاز العصبي المستقل، وقد تتغير الحالة في شدتها وتذبذبها عبر الزمن ويمكن قياسها عن طريق الدرجة التي يحصل عليها المستجيب من خلال إجابته على مقياس قلث الامتحاني المتبنى في البحث الحالي.

\section{الفصل الثاني: الخلفية النظرية:}

القلق ألامتحانى: يعد القلق من الانفعالات الإنسانية الأساسية وجزءاً طبيعياً في كل آليات السلوك الإنساني وهو يمثل أحد أهم الاضطر ابات المؤثرة على صحة الفرد ومستقبلة، إضـافة الى تأثنيره السلبي في مجالات الحياة المختلفة. إذ يعتبر القلق من العوامل الرئيسية المؤثرة في الثخصية الإنسـانية، وهو بمثابـة المرض الجرضية الجوهري المشترك في الاضطر ابات النفسية بـل وفي إمر اض عضـوية مختلفة، ولو تطلع الإنسـان إلى ماضـي حياتهـ لوجدها سلسلة متعاقبـة من حسالات القلق تقل وتزيد تبعـا لأحداث الحيـاة، والتطور الحضـاري و التكنولوجي.

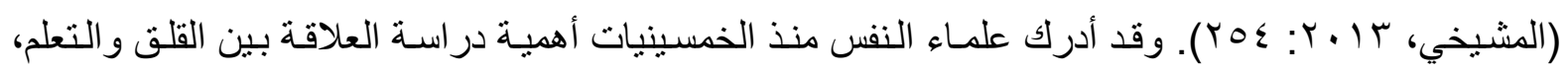

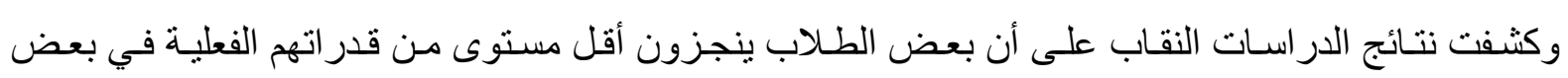
المو اقف التي تتسـ بالضـغط و التقويم كموقف الامتحانـات و أطلقوا على القلق في هذه المو اقف تسمية القلق ألامتحاني باعتبار يشير إلى نوع القلق العام الذي يظهر في مواقف معينـة مرتبطة بموقف (Test Anxiey)

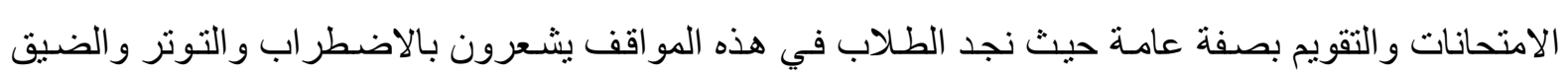

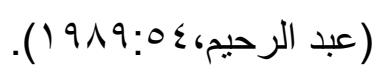

مصادر قلق الامتحان: يثير التربويون في هذا المجال إن لقلق الامتحان مصادر متعددة منها ما يلي:

$$
\begin{aligned}
& \text { 1 - طموحات وتوقعات و اهتمامات بالأسرة. } \\
& \text { r- استعداد الطالب نفسه. } \\
& \text { r- المعلم وطر ائق التدريس. }
\end{aligned}
$$


ع- طر ائق التقويم المتبعة والظروف المحيطة بالامتحانات.

$$
\text { هـ - عادات الدر اسة الجديدة (الطيب، } 997 \text { (: 1). }
$$

وقد تكون مصـادر القلق كثيرة للدى الطلبـة وخصوصـا بعد التطور التقني والتكنولوجي ونتيجـة المشتتات الفكريـة التي أصبحت أكثر في الوقت الحسالي لزيـادة منطلبـات التعليم، فنلاحظ الطلبـة يضيعون الوقت ورلا يستطيعون التركيز في الامتحانات ويعانون من الفنل و الإخفاق من تجاوز الامتحانـات نتيجـة الظروف الحياتيـة الكثيرة متعلقة بعدة جو انب منها سياسية و اقتصادية واجتماعية .

أسباب قلق الامتحان: أن من أهم أسباب القلق التي يرها المهتمون في مجال الصحة النفسية في المجال التربوي

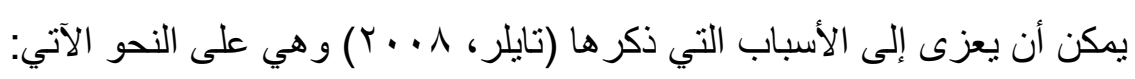

$$
\begin{aligned}
& \text { ا. . نقص المعرفة بالموضو عات الدراسية. } \\
& \text { r. نقص الرغبة في النجاح بتفوق. }
\end{aligned}
$$

r. و وجود مشكلات في تعلم المعلومـات أو تنظيمها أو مر اجعتهـا قبـل الامتحسان،أو استدعائها في موقف الامتحان ذاته.

ع. ارتباط الامتحان بخبرة الفشل في حياة الطالب، وتكرار مرات الفشل. ๑. قصور في الاستعداد للامتحان كما يجب، وقصور في مهار ات أخذ الامتحان. 7. التمركز حول الذات، ونقص الثقة بالنفس. V. الاتجاهات السالبة لدى الطلاب و المعلمين و الوالدين نحو الامتحانات. ^. صعوبة الامتحانات و الثعور بان المستقبل يتوقف على الامتحانات. 9 . الضغوط البيئية، وخاصة الأسرية، لتحقيق مستوى طموح لا يتناسب مع قدرات الطالب. • . الضغوط المباشرة حين يتعرض الطالب للتهديد أو يواجه الفثل.

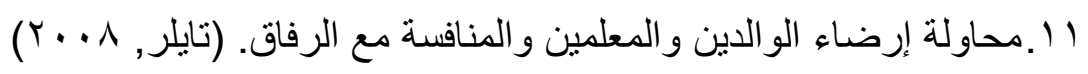

فيجد الباحث إن من أهم أسباب القلق عند أداء الاختبار (الامتحان) هو عدم الاستعداد النفسي وعدم إكمـال حفظ أو فهم المادة الدر اسية يسبب حالة حرجة لدى الطلب مما يؤدي إلى الخوف من الفنشل وخذلان الآخرين الذين يثقون به أو يعتمدون عليه من الأهل و الأصدقاء فيكون رد الفعل كبير في نفسـه أو ارتباط ذلك في طموحاته الهـ وتحقيق رغباته المستقبلة فيخشى عدم النجاح. أعراض ومظاهر قلق الامتحـان: أن من أعر اض قلق الامتحـان التي يمكن ملاحظتها على الطالب إثتاء أداء الاختبار(الامتحان)و هي على النحو الآتي: 
ا. التوتر والأرق وفقدان الثهية، وتنلط بعض الأفكار الوسواسية قبل و أثناء ليالي الامتحان. r. كثرة التفكير في الامتحانات والانشغال قبل و إثناء الامتحان في النتائج المترتبة عليها. r. تسارع خفقان القلب مع جفاف الحلق والثفتين وسر عة التنفس وتصبب العرق، و ألم البطن و الغثيان.

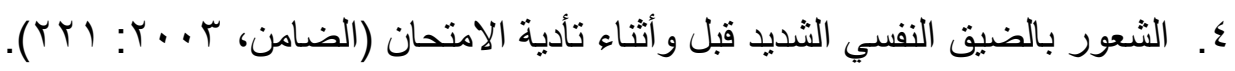
○. الخوف و الر هبة من الامتحان و التوتر قبل الامتحان. 7 7. اضطر اب العمليات العقلية كالانتباه و التركيز و التفكير. V. الارتباك و التوتر ونقص الاستقر ار والأرق ونقص التقة بالنفس.

^. تشتت الانتباه وضعف القدرة على التركيز واستدعاء المعلومات أثناء أداء الامتحان. 9. الرعب الانفعالي الذي يشعر فيه الطالب بـان عقلة صفحة بيضـاء وانـه نسى مـا ذاكر بمجرد الاطلاع على ورقة أسئلة الامتحان. • ا.وجود تداخل معرفي، يتمثل في افكار سلبية غير مناسبة عن الامتحانـات، ونقص إمكانيـة المعالجـة

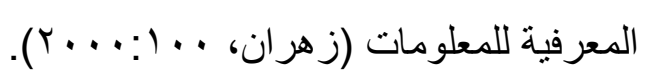

فيرى الباحث أن أعر اض القلق ألامتحـاني قد تختلف من طالب إلى أخر إلا أن هنـاك بعض التصر فات و الحركات التي يمكن ملاحظتها على الطالب أثناء أداء الاختبار (الامتحان) وتشير إلى عدم استعداده النفسي مما يمكن ان نعزو ها إلى أعر اض قلى الامتحان.

\section{النظريات التي فسرت قاق الامتمان:}

أولا: النظرية النفسية: يعتقد فرويد أن القلق هو بمثابة نوع من ازيز العقل اللاوعي الذي يصبح أحيانـا زلزالاً أو انفجارً منبعثاً من المشاعر المكبوتة التي لن يكون بوسعها البقاء تحت الغطاء، وان الهدف من هذا الأزيز

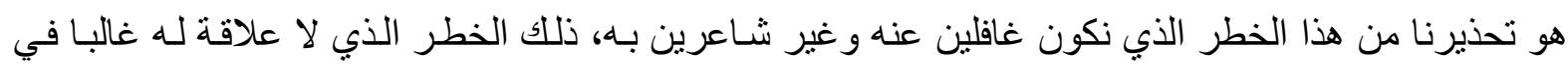

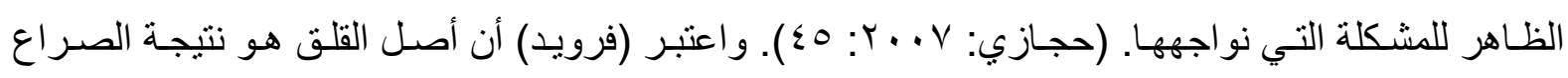

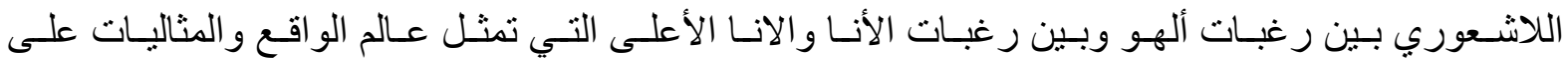

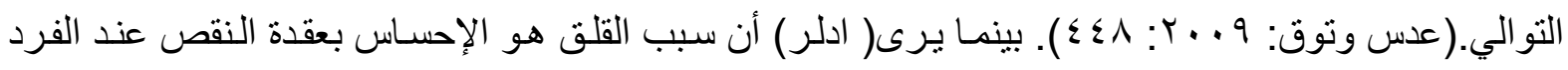
سوى كان هذا النقص حقيقيا أو متوهما في حين تؤكد (كارين هورني ) ان سبب القلق تتحكم فيه عوامل ثلاثنة

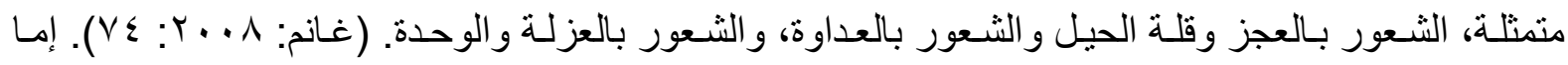
أصحاب المدرسة السلوكية، فينظرون إلى القلق ما هو إلا شي متعلم ومكتسب من البيئة الخارجية التي يتواجد

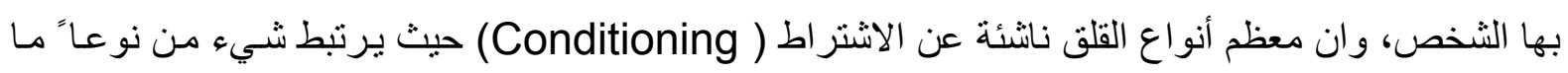
ارتباط عارضا بخبر يثير القلق وغالبا ما تكون خبرة من النوع الخطر ـ وان الأبحاث الحديثة تدل على ان كل من الصر اع المعرفي والمو اقف الخطرة المحتملـة يمكن ان تثير القلق وتسبب اعر اضـا فسيولوجية خاصـة بـه. ( $($ (دافيدوف، 
ثانياً: النظرية الاجتماعية: ذهب أصحاب هذا الاتجاه الى ان المواقف الاجتماعية هي التي تهيئ الفرد للدخول إلى معترك القلق العصابي، فالامتحان مثلا عبارة عن موقف تقويمي للطالب، الا إن الثقافة المجتمعية السـائدة تؤكد على اجتياز الامتحان والنجاح فيه مما قد يشحن الفرد بالعديد من أسـاليب التوتر والتي تظهر بوادرهـا في

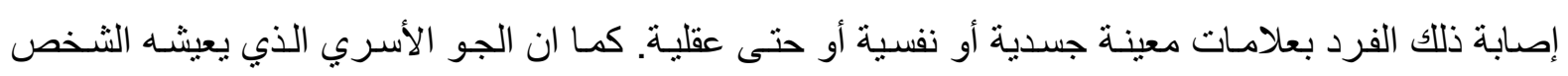

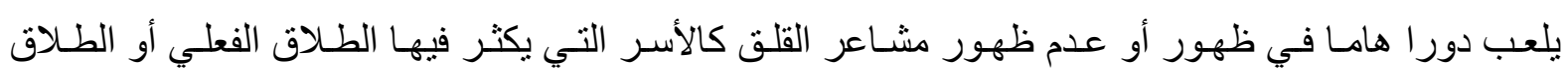

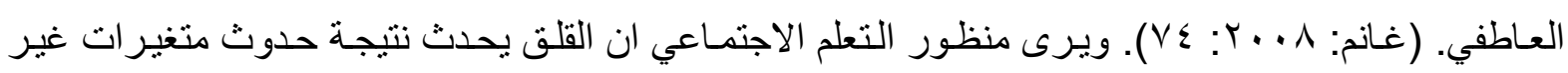
مرغوبة مع وجود استعداد نفسي عند الثخص لامتلاكه مفهوما معرفيا سلميا لقدر اته، ورغم ان القلق كونه يعبر

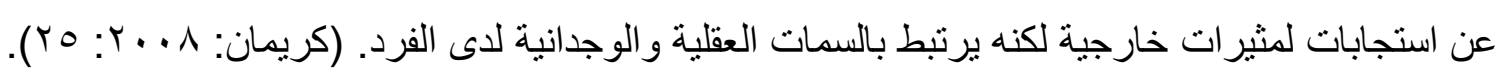
ثالثأ:نظرية نوكس ( Nokes 1991) أكد نوكس في نظريته لمواجهة القلق، على العو امل الثخصية للفرد

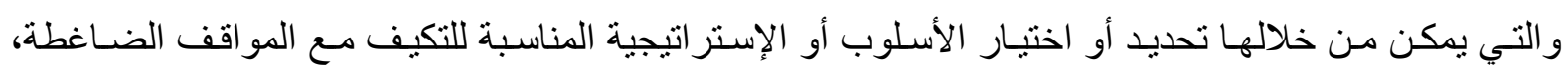
بحسب شخصباتهم ومقدار الدعم النفسي أو الاجتماعي الذي ينوفر لايهم وان أحداث الحياة الضـاغطة جدا يمكن

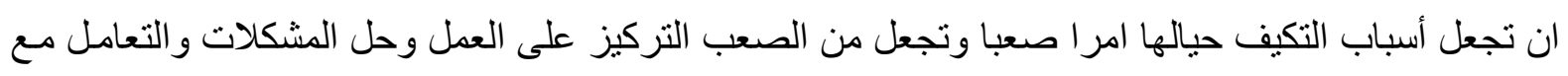
الإحباط (الزغول، الهنداوي، ؟ . . ب: 9 (1) ). وترى هذه النظريـة ان الخطوات التي تسـاعد الفرد على التعامل

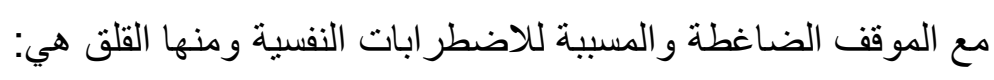

$$
\begin{aligned}
& \text { ا . . تحديد الحدث. } \\
& \text { r. استقرار اكبر عدد من الأفكار التي تساعد على تخفيف الحدث. } \\
& \text { r. تخيل العمل بعدة أساليب للسيطرة على الحدث. } \\
& \text { ع. التفكير بالأساليب التي يستخدمها الإفر اد لذلك الحدث. } \\
& \text { ๑. مناقثة الأساليب المحتملة مع شخص أخر. }
\end{aligned}
$$

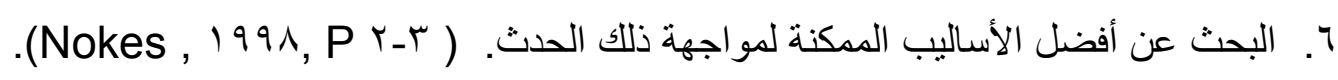

رابعاً: نظرية الحالة (السمة): لقد توصل كاتل وسبيلبيرجر (Kattle\&spilberger) الى التمييز بين الجانبين للقلق. جانب القلث الذي نشعر به في موقف معين ويزول بزو اله، وجانب الاستعداد للقلق أو الاستهداف للقلق

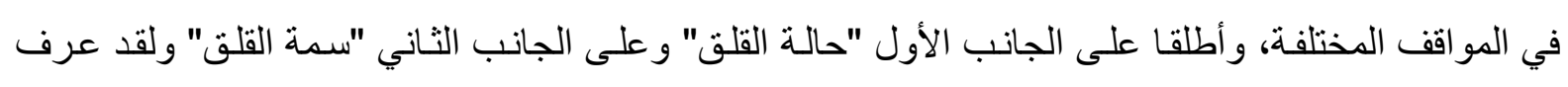

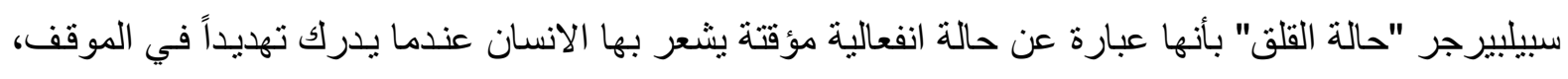
فينشط جهازه العصبي اللاإرادي، وتتوتر عضلاته ويستعد لمواجهة هذا التهديد.

فالثخص صاحب سمة القلق المرتفعة يكون لايه استعداد عـال للقلق مـا يجعله بستجيب لمو اقف التهديد و الثدة بخوف شديد لا يتناسب مع الموقف الذي تعرض له، أمـا الثخص صـاحب سمة القلق المنخفضـة فإنه يستجيب لموقف التهديد والثدة بخوف عادي يناسب ما في الموقف من خطر موضـعي. أن سمة القلق لا تظهر مباشرة في السلوك بل تستتتج أو يستدل عليها من تكرار ارتفاع حالة القلق وشدتها لدى الفرد على امتداد الزمن. ويتميز

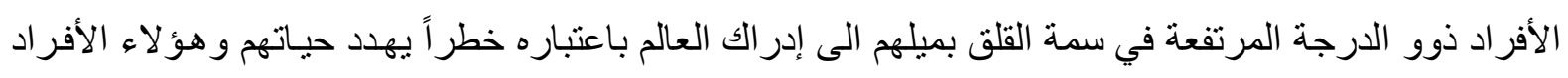


أكثر تعرضاً للمو اقف العصبية.(القريطي، ؟ . . ץ: 7 7). لذلك فإن قلق الحالة يقابل القلق الموضعي عند فرويد أي أن مصدرة معروف ويزول بزوال الموقف الخطر أمـا قلق السمة فهو القلق العصـابي حيث إنـه شديد ولا

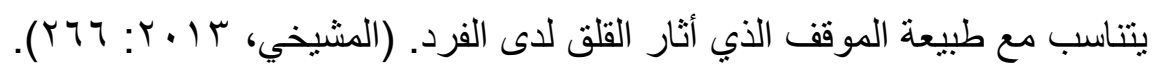

دراسات سابقة:

يتتاول الباحث في هذا المحور الدّر اسات السابقة المتصلة بموضوع البحث الحسالي ،والاستفادة ممّا توصل

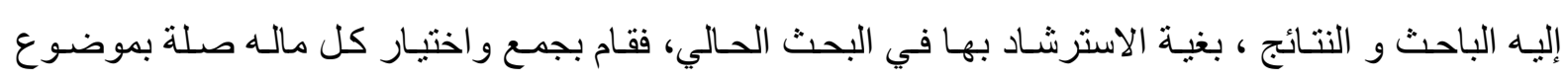
البحث،و التي تم عرضها بشكل موجز ومرتب تنازلياً حسب تسلسل زمن حدوثها ،من القديم إلى الحديث من

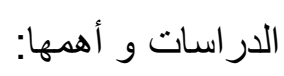

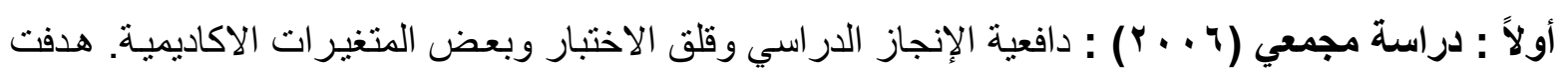
الدر اسة إلى معرفة طبيعة دافعية الإنجاز الدراسي وقلق الاختبار في بعض المتغيرات الأكاديمية (كالتحصيل

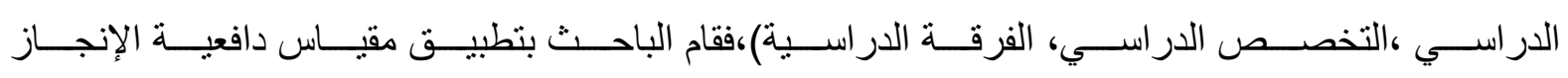

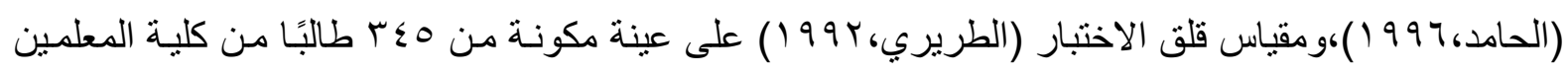
في جـاز ان، وقد توصلت الدراسـة إلى النتائج التاليـة: وجود علاقـة ارتباطيه سـالبة دالـة إحصـائيًا ،بين دافعيـة الإنجاز الدر اسي، وقلق الاختبار، وكذلك وجود فروق ذات دلالة إحصـائية في مستوى دافعية الإنجاز الدراسي بين الطلاب مرتفعي التحصيل الدر اسي، و الطلاب منخفض بالتحصبل الدراسي، وذلك لصسالح الطلاب مرتفعي

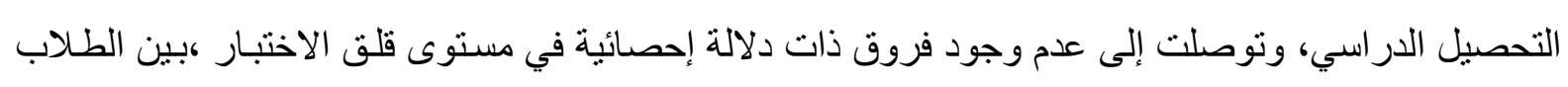

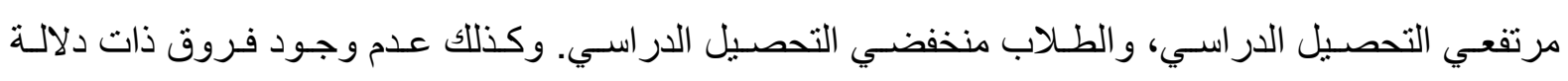
إحصـائية في مستوى قلق الاختبـار، بين الطـلاب في التخصص العلمي، والطـلاب في التخصص الأدبس.

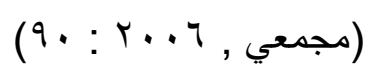

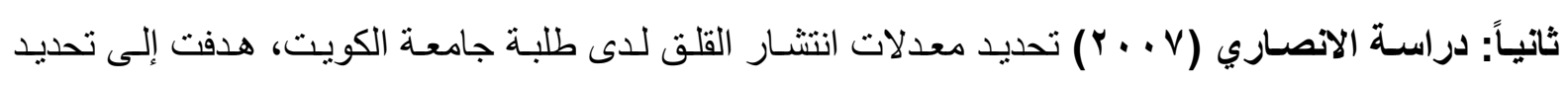

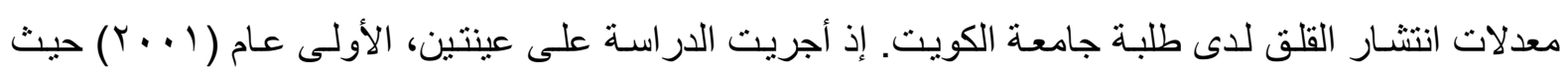

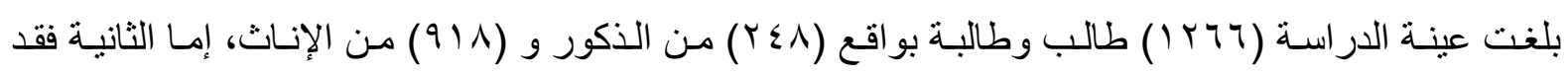

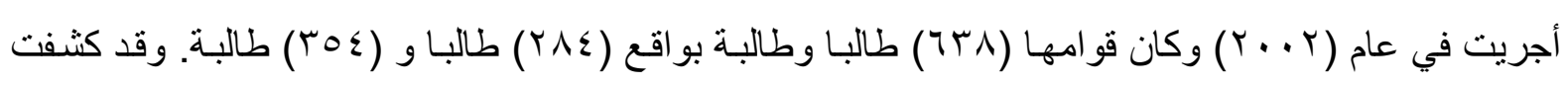
نتائج هذه الدراسـة عن ارتفاع معدلات انتشار القلق لدى الطالبات بنسبة (9 (1\%) على حين كانت نسبة عند الطلبة (r ( \%) وكذلك وجود فروق جوهريـة بين الجنسين في القلق حيث حصلن الطالبـات على متوسطات

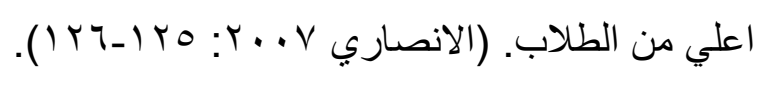

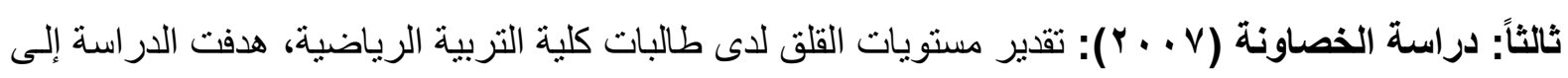

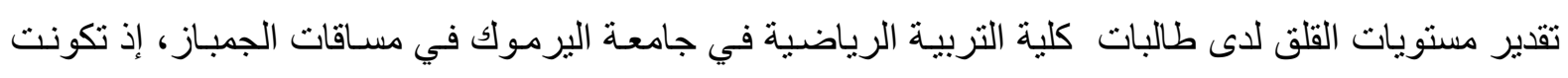

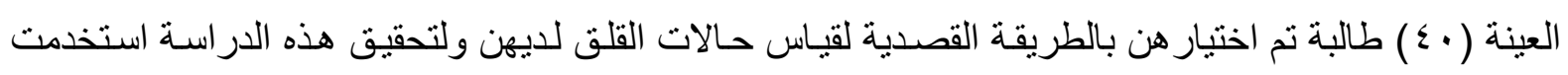
الباحثة مقياس سبيلبيرجر لقياس القلق، و أظهرت النتائج عن وجود القلق بثـكل عـام للدى إفراد العينـة كمـا

\section{$-T \leq \varepsilon-$}


أظهرت عن وجود فروق بين الطالبات في فيئتي البحث في قلق الحالة قبل الاختبار الامتحسان بين لا توجد

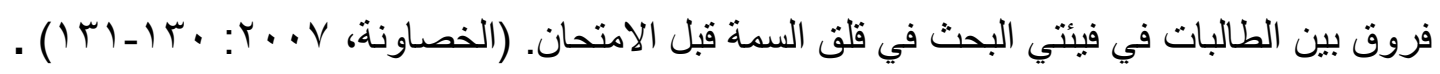
رابعاً : دراسة أبو عزب (1 . ㄷ): فعالية برنامج إرشادي مقترح لخفض قلق الاختبار، هدفت الدراسة التعرف

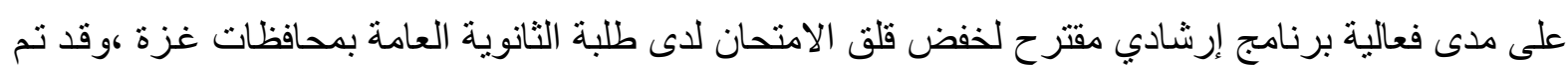

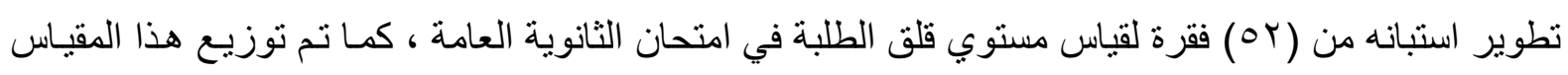

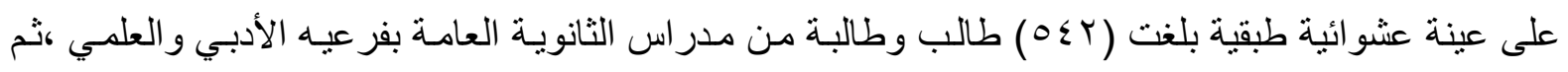
اختير من هذه العينة أكثر الطلاب الذي نسجلو ا أعلى درجات على مقياس قلق الامتحسان حيث تم اختيار ( • (ب) طالب ، توزعوا على مجمو عتين، حيث شملت المجموعـة التجريبية (0 10) طالب، وشملت المجموعـة الضـابطة علي (10) طالب وتم تطبيق البرنامج الإرشادي عليهم وقد توصلت الدراسة إلى النتائج التالية:توجد فروق ذات دلالة إحصـائية عند مستوى الدلالة (0 . . • ) في متوسطات درجـات مستوي قلق الامتحسان لدي طلبـة الثانويـة العامة بمحافظات غزة تعزى لمتغير الجنس ولصالح الإناث. وكثفت أيضـاً لا توجد فروق ذات دلالـة إحصـائية عند مستوى الدلالة (0 . . • ) في منوسطات درجات مستوى قلق الامتحـان لدى طلبـة الثانويـة العامـة بمحافظـات

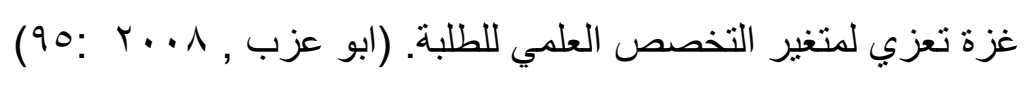

\section{مناقشات الدراسات السابقة:}

استعرض الباحثث عددا مـن الدِر اسـات السـابقة حيث أنَّ أغلب الدّر اسـات قد ركزت على القلت النفسي في الامتحان، فاستفاد الباحث من الدّر اسات السيّابقة في تحديد وصياغة المشكلة وأسئلتها وتحديد مجالاتها و أدو اتها لتظهر بالثكل الذي عليـه الآن، حيث كان البحث منسجماً مـع الذّر اسـات الستّابقة من حيث الأهداف التي في في الكثف على درجة القلق النفسي في الامتحان.ويمكن مناقتتها ضمن المحاور الآتية :

ا- الأهداف: اتفقت الدراسات السابقة من حيث أهدافها إذ هدفت إلى التعرف على مستوى القلق وتحديد معدلات انتشاره بين الطلبة إما الدر اسة الحالية فقد جاءت مطابقة للار اسـات السـابقة حيث هدفت إلى الى التعرف على مستوى القلق لدى طلبة الجامعة وكذلك التعرف على دلالة الفروق في مستوى القلق

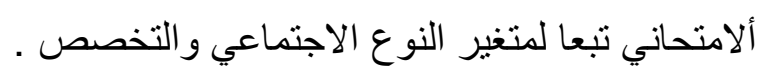

r- العينة: تباينت الدراسات في إعداد عينتها مـا بين عينة صغيرة و عينة كبيرة حيث بلغت عينة دراسـة

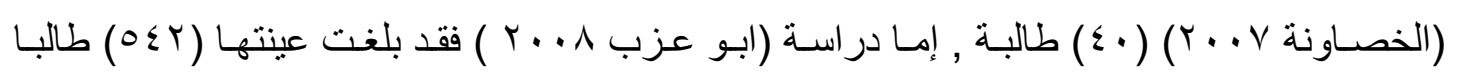

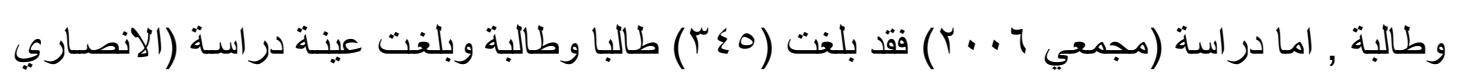

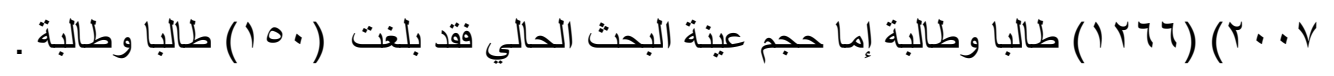
r- أدوات الدر اسـة : استخدمت الدر اسـات السـابقة أدوات تتناسب مـع طبيعـة البحوث و أهدافها إمـا البحث الحالي فقد تبنى الباحث مقياس (ابو عرب ء 99 ( ) . 
ع - الوسائل الإحصائية : استخدمت الدر اسات السابقة وسائل إحصائية مختلفة بـاختلاف أهدافها إمـا البحث

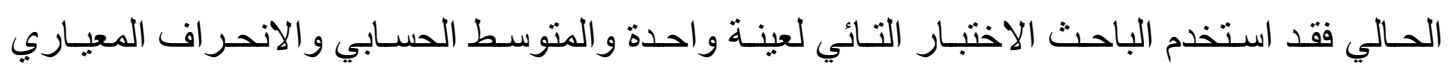
والاختبار التائي لعينتين مستقلتين ومعادلة ألفا كرونباخ ومعامل ارتباط بيرسون . هـ النتائج : اتفقت الدراسات السابقة في بعض النتائج واختلفت في البعض الأخر إمـا نتائج البحث الحسالي فستتضح في الفصل الرابع من البحث . اتفقت الدِّر اسات السّابقة مع البحث الحالي من حيث المنهج البحث، إذ اعتمدت المنهج الوصفي وأجريت

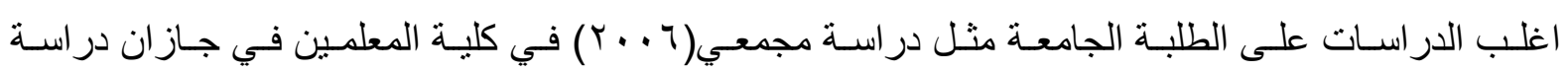

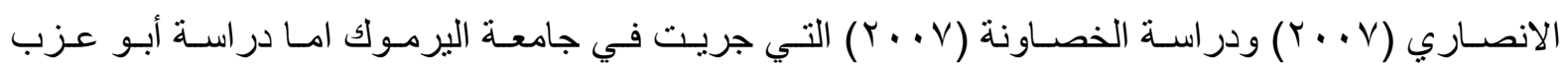

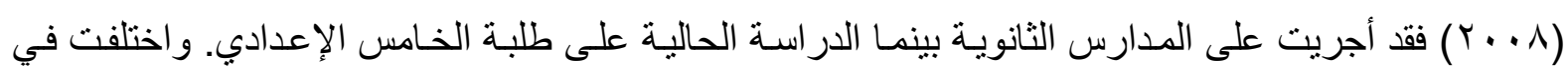

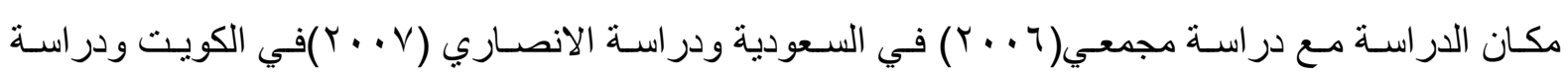

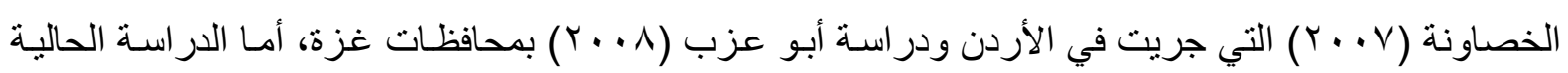
أجريت في العر اق في محافظة ذي قار.

\section{الفصل الثالث- هنهمية البحث وإجراءاته:}

يتضمن هذا الفصل وصفاً للإجر اءات التي اعتمدت لتحقيق أهداف البحث بداً من مجتمع البحث و عينته ووصف خصائصها واختيار أدوات البحث لتحقيق أهدافه ومعالجة بياناته بالوسائل الإحصائية المناسبة. أولا: مجتمع البحث: يتمثل بطلبة الخـامس الإعدادي في مركز قضـاء قلعة سكر بتخصصيها العلمي والأدبي

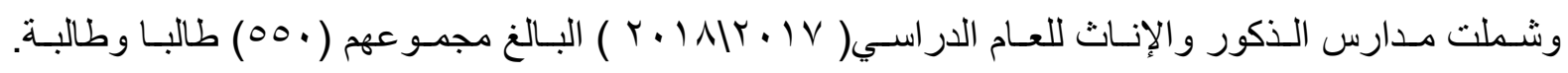

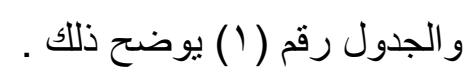

جدول رقم( (1) يوضح مجتمع البحث موزع حسب متغير (الجنس والتخصص)

\begin{tabular}{|c|c|c|c|c|}
\hline \multirow{2}{*}{ مجموع الطلبة } & \multicolumn{2}{|c|}{ الخامس } & \multirow{2}{*}{ عدد المدارس } & \multirow{2}{*}{ المدارس } \\
\hline & الأدبي & العلمي & & \\
\hline rr. & 10. & $1 \wedge$. & 7 & بنين \\
\hline YY. & $11 \leqslant$ & 1.7 & $\varepsilon$ & بنات \\
\hline 00 . & Y Y & Y^T & 1. & لمجموع الكلي \\
\hline
\end{tabular}

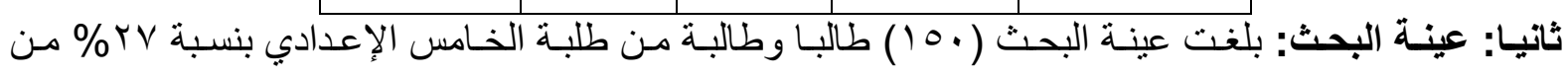
المجتمع الكلي، وقد تم اختبار هم بالطريقة الحصر و الجدول رقم (r) يوضح ذلك. جدول رقم (ץ) يوضح عينة البحث موزع حسب متغير (الجنس والتخصص).

\begin{tabular}{|c|c|c|c|c|}
\hline \multirow{2}{*}{ مجموع الطلبة } & \multicolumn{2}{|c|}{ الخامس } & \multirow{2}{*}{ عدد المدارس } & \multirow{2}{*}{ المدارس } \\
\hline & الأدبي & العلمي & & \\
\hline vo & $r$. & $\leqslant 0$ & $\varepsilon$ & بنين \\
\hline vo & ro & $\varepsilon$ & $r$ & بنات \\
\hline 10. & Vo & Vo & 7 & المجموع الكلي \\
\hline
\end{tabular}


ثالثا: أداة البحث: بعد اطـلاع الباحث على بعض المقـاييس العراقيـة و العربيـة وجد مـن المناسـب اسـتخدام مقياس(أبو عرب، ع 9 ( ))وقد تم اختيار هذا المقيساس دون غيرة لأن فقر اتـه تغطي كل أثنكال وأنواع القلق ألامتحاني.

رابعا: وصف المقياس: يتكون المقياس من (Or) فقرة تمثل كل واحد منها استجابة سلوكية وتتكون الإجابـة عن

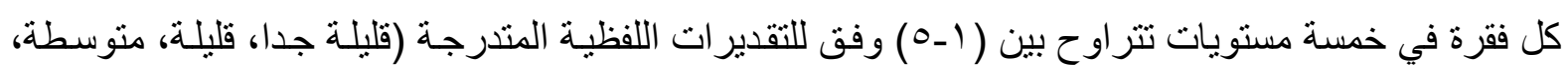
كبيرة، كبيرة جدا ) وتدل الدرجة العالية على ارتفاع مستوى القلق والدرجـة المنخفضـة على انخفاض مستوى

الخصـائص السـايكومترية لمقيساس القلث ألامتحساني: صـلاحية القياس: يذكر ابيل (Eble) إن أفضل طريقة

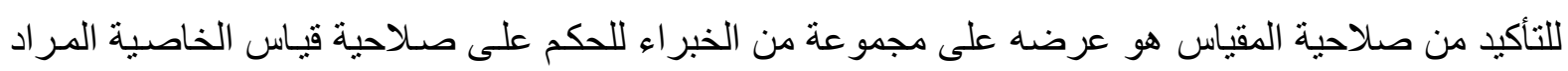

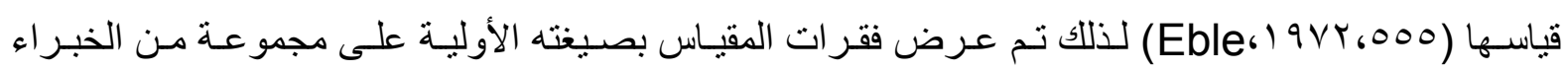
المتخصصين بهذا المجال و الذي بلغ عددهم (^) خبر اء، لغرض الحكم على صـلاحية الفقرات، وتحديد الصـالح منها و غير الصالح و أجراء التعديل المناسب عليها، وفي ضوء أراء الخبراء تم تعديل بعض الفقرات بعد اتفاق

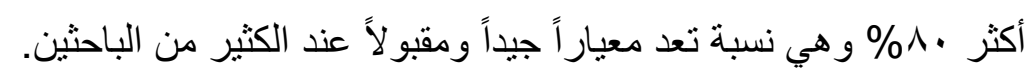

وفيما يأتي توضيح للتبيت من هذه الخصائص للمقياس:

الصدق Validity: يعد الصدق من أهم الخصائص السيكومترية التي ينبخي توفرها في المقياس النفسي، وهو

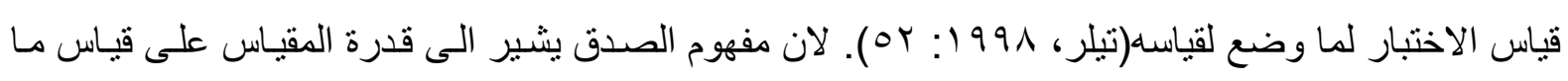

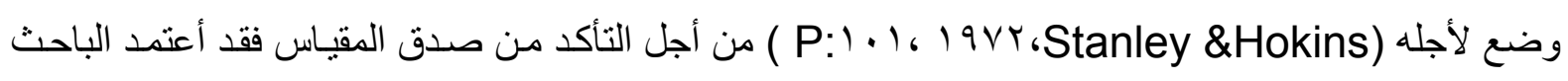

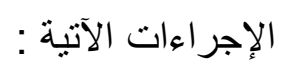

الصدق الظاهري Face Validity: يعد هذا النوع من الصدق من الخصـائص المهمـة في بنـاء الاختبـار ات و المقاييس فهو من الإجـراءات المرغوب فيها في المراحل الأولى مـن إعداد المقيـاس (أبو حطب عنمـان،

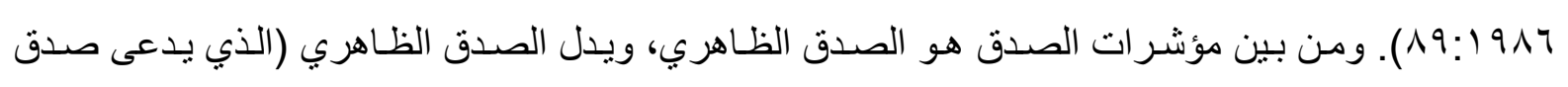

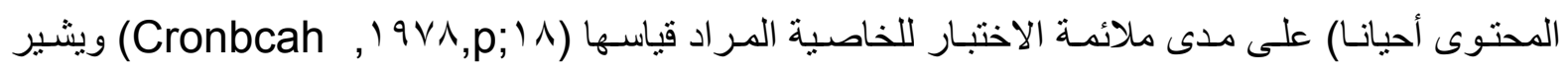
المتخصصسون في المجال النفسي إن أفضل وسيلة لتقرير الصدق الظـاهري للمقياس هو عرض فقراته على

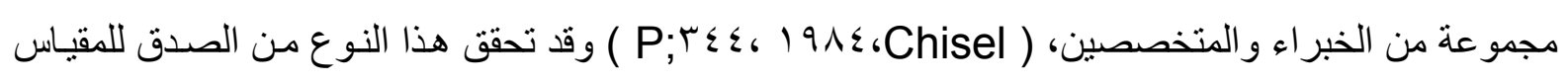
الحالي كما ذكر سلفاً وذلك عندما عرض على مجمو عه من الخبر اء و المتخصصين في العلوم التربويـة و النفسية للأخذ بآر ائهم حول صلاحية فقرات المقياس لما وضعت لقياسه .

الثبات Reliability: يعد الثبات من خصائص المقياس الجيد، ويشير اتساق الدرجات التي جمعت من الأفر اد

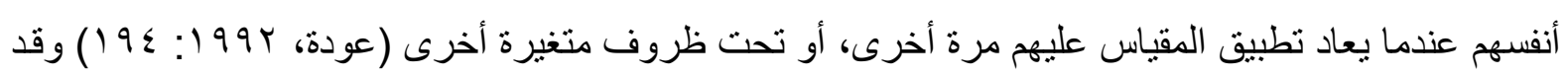
تم استخر اج ثبات المقياس بالطريقة الآتية. 
طريقة إعادة الاختبار Test - R-Test: يكثف الثبات بطريقة الإعـادة عن استقرار النتائج التي يقدمها الاختبار أو المقياس عبر فاصل زمني معين ويسمى معامل الثبات المستخرج بهذه الطريقة بمعامل الاستقرار (

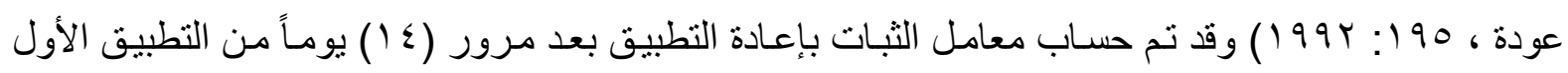

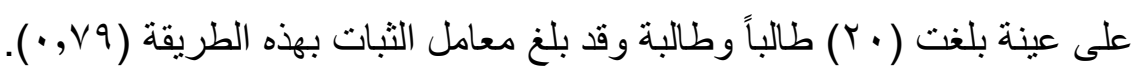

خامسا- الوسائل الإحصائية: استخدم الباحث الوسائل الإحصائية الآتية:

ا. . الاختبار التائي لعينة واحدة: للتعرف على القلق ألامتحاني لدى طلبة الخامس الإعدادي. r. الاختبار التائي لعينتين مستقلتين: لإيجاد الفروق في القلق ألامتحاني بحسب متغير الجنس(ذكور- إناث) r. معامل ارتباط بيرسون لإيجاد الثبات بطريقة الاختبار و إعادة الاختبار لمقياس القلق ألامتحاني.

\section{الفهل الرابع - عرض النتائج وهناقشتتها وتفسيرها:}

ويتضمن هذا الفصل عرض لنتائج البحث وبحسب الأهداف ومناقتنها مـع بيان الاستنتاجات التي تم التوصل إليها في ضوء النتائج واهم التوصيات و المقترحات هرضئ

الهذف الأول: التعرف على درجة القلق الامتحاني لاى طلبة الخامس الإعدادي في أداء الاختبار الامتحان؟ وتحقيقا لذلك استخدم الباحث الاختبار التائي لعينة واحدة حيث أظهرت النتائج وجود فروق دالة إحصـائية بين

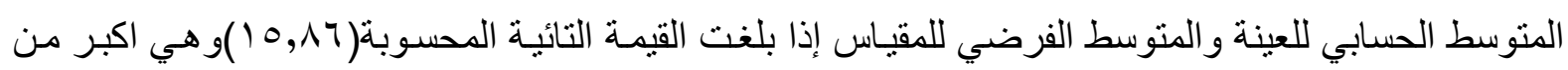

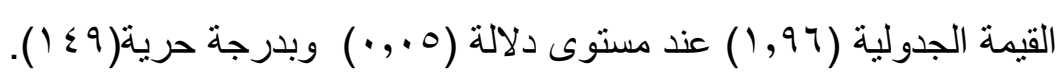

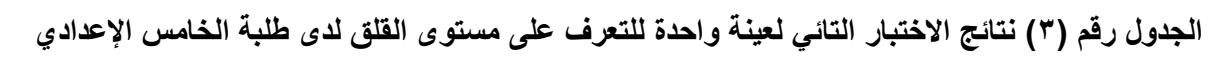

\begin{tabular}{|c|c|c|c|c|c|c|c|}
\hline مستوى الدلالة & القيمة التائية & الحرية & القيمسة التائية & الفرضي & الالمعرافي & الحسابي & العدد \\
\hline$\cdot, \cdot 0$ & 1,97 & $1 \leq 9$ & $10, \wedge 7$ & 107 & $1 r, .0$ & $1 \checkmark \wedge, \wedge r$ & 10. \\
\hline
\end{tabular}

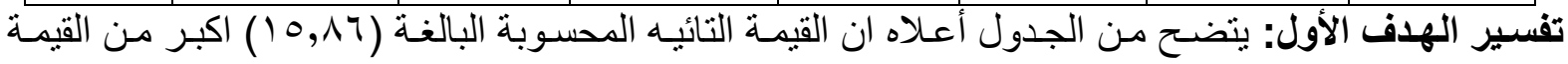

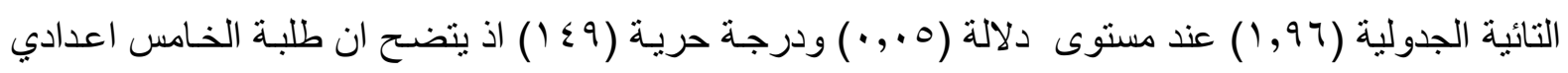

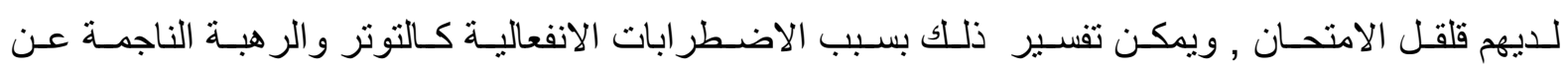
الضغوطات الناتجة عن مو اقف التقويم كما أنهم يشعرون ويدركون بان المواقف التقويمية مصدر للتهديد وبهذا يكون ذلك مصحوبا بانعدام الر احة النفسية وتوقع العقاب و أيضـا يتصف باضطر ابات انفعالية مصحوبة بردود بـون أفعال جسمية وفسيولوجية وظهور عدم التوازن بالجوانب المعرفية والرغبة في الهروب من الموقف، كل هذه

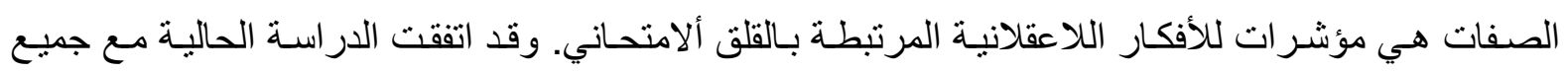
الدراسات السابقة .

الهذف الثاني: التعرف على درجة القلق الامتحاني لاى طلبة الخـامس الإعدادي في أداء الاختبار (الامتحان) تُبعا لمتغير الجنس؟ 
لمعرفـة دلالـة الفروق في القلق ألامتحاني بحسب متغير النوع الاجتمـاعي (ذكور-إنـاث) اذ استخدم الباحث الاختبار التائي لعينتين مستقلتين، وقد أظهرت النتائج وجود فروق ذات دالة إحصـائية بين متوسطي درجات

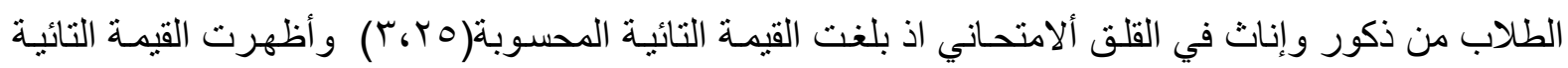

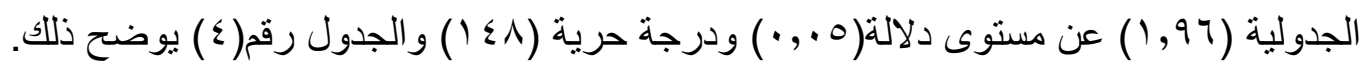
جدول رقم \&نتائج الاختبار التأي لعينتين مستقلتين لتعرف دلالة الفروق في مستوى القلق الامتحاني لاى طلبة الخامس العلمي تبعاً لمتنير الجنس

\begin{tabular}{|c|c|c|c|c|c|c|c|}
\hline الدلالدة & القيمة التائية & درجة الحرية & القيمة التائية & الانحراف & الحسابي & العدد & الجنس \\
\hline \multirow{2}{*}{.06.} & \multirow{2}{*}{94.1} & \multirow{2}{*}{$1 \leqslant 1$} & \multirow{2}{*}{ ro,r } & . Tralr & $\Lambda .96 \wedge r$ & vo & ذكور \\
\hline & & & & $.99,14$ & rol, & vo & إناث \\
\hline
\end{tabular}

تفسير الهـف الثاني: يتضـح مـن الجدول أعـلاه أن النتيجة تشير إلى وجود فروق ذات دلالـة إحصـائية بين

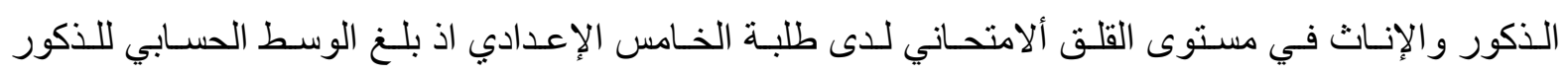

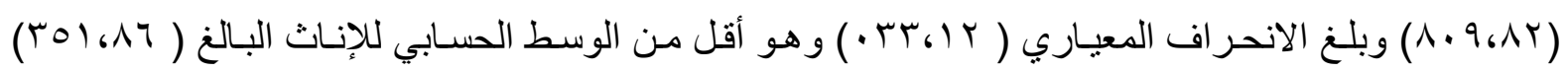

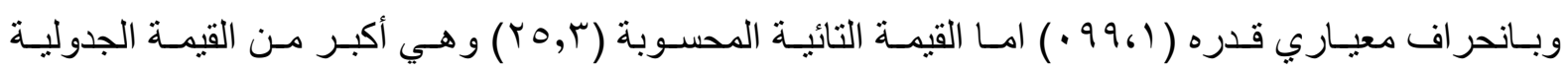

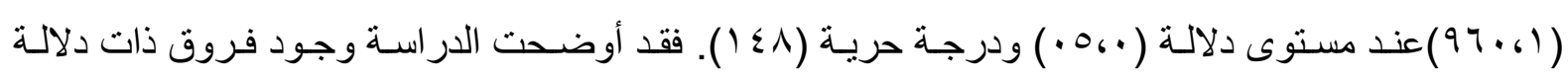

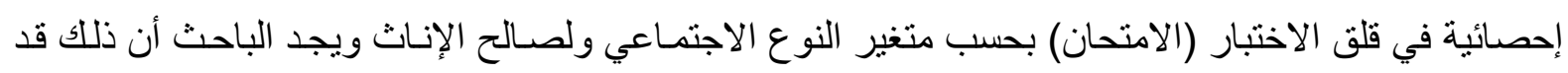

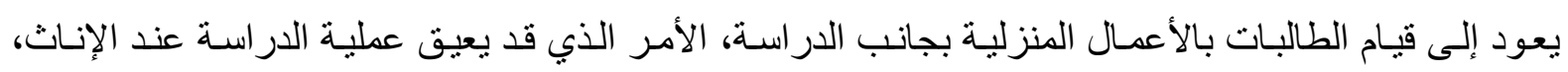

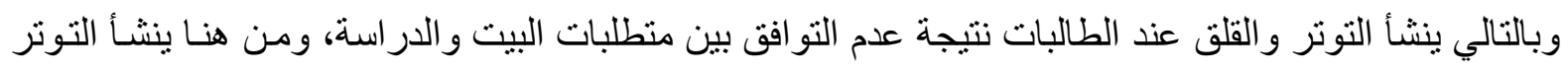
و القلق، وتزداد حدته كلما اقترب موعد الامتحانـات، اضـافة إلى طموح الفتيات الز ائد بالحصول على معدلات

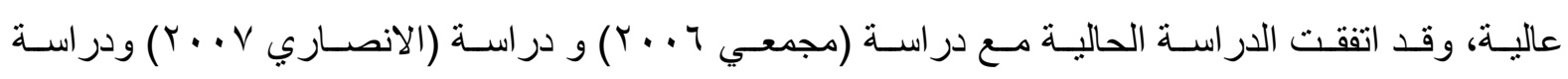
(الخصاونة V . . . أن هناك فروق دالة إحصائية في متغير الجنس ولصالح الإناث.

الهدف الثالث: التعرف على درجـة القلق الامتحاني للى طلبة الخـامس الإعدادي في أداء الاختبار الامتحان تبعاً لمتغير التخصص (علمي - أدبي)؟ للتعرف على دلالة الفروق في مستوى القلق ألامتحاني لاى طلبـة الخامس الإعدادي تبعاً لمتغير التخصص تم إيجاد الوسط الحسابي و الانحر اف المعياري لكل منهما والقيمة التائية المحسوبة والجدولية كما مبين في الجدول

جدول رقم (0) نتائج الاختبار التائي لعينتين مستقلتين لتعرف على دلالة الفروق في مستوى القلق ألامتحاني

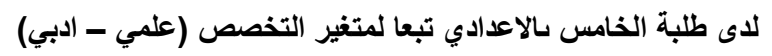

\begin{tabular}{|c|c|c|c|c|c|c|c|}
\hline مستوي & الجيدة التائية & القيمسوبة التائية & درجة الحرية & المعياري & الحسابي & العدد & التخصص \\
\hline \multirow[t]{2}{*}{.06.} & \multirow[t]{2}{*}{9961} & \multirow[t]{2}{*}{$r \mu, r$} & \multirow[t]{2}{*}{$1 \leqslant \Lambda$} & rargl. & 99.17 & Vo & أدبي \\
\hline & & & & VYY،A & $1 \cdot Y_{6} \Lambda \leqslant$ & vo & علمي \\
\hline
\end{tabular}


تفسير الهـف الثالث: يتضـح من خـلال الجدول أعلاه أن هناك فروق دالـة في مستوى القلق ألامتحـاني بين طلاب وطالبـات الخـامس الإعدادي ولصـالح التخصص العلمي، ويمكن تفسير ذلك أن أفراد العينـة مـن ذوي التخصص العلمي ربما يعانون من صعوبة المواد العلمية التي تتطلب منهم الجهد والمثابرة أكثر من التخصص الأدبي كما أن طلبة التخصص العلمي يطالبون بالجانب العملي في المختبرات إضافة إلى الجانب النظري وهذا

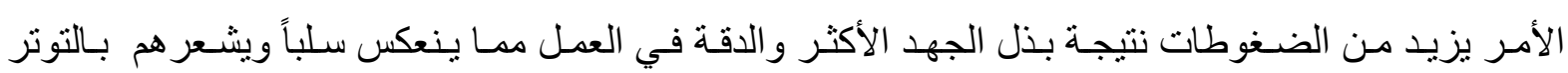
و الإنهاك الجسدي و الفكري الذي يساعد على ارتفاع مستوى القلق، وهذه النتيجة تتفق مع نتائج دراسـة ودر اسـة

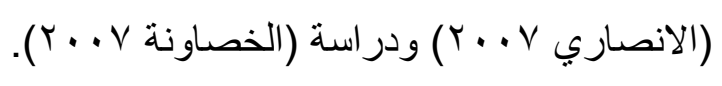

الاستتتاجات: في ضوء النتائج التي توصل إليها الباحث بتطبيق أداة البحث ، جرى استنتاج ما يأتي:

$$
\text { l. (إن طلبة الخامس الإعدادي يعانون من قلق الامتحان. }
$$

r. إن طالبات الخامس الإعدادي يشعرن بقلق الامتحان أكثر من الطلبة الذكور.

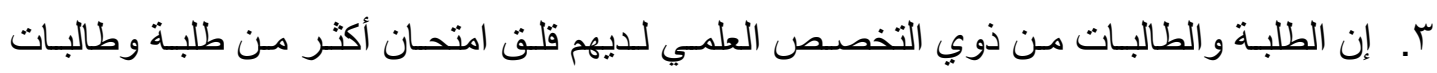

$$
\text { التخصص الأدبي. }
$$

$$
\text { التوصيات: في ضوء النتائج توصل الباحث الى بعض من التوصيات وهي: }
$$

ا. . عدم تخويف الطلبة إثناء تأديتهم للامتحان بل إثعار هم بالتقبل والمودة والعلاقة الإنسـانية الطيبة وتخفيف

$$
\text { الضغوطات النفسية على قدر الإمكان. }
$$

r. محاولة تغيير الأساليب المتبعة في التعليم من قبل الأستاذة وعدم استخدام التهديد والكف عن التهويل. r. تتمية وتعزيز الثقة بالنفس لدى الطلبة بإمكانياتهم والتقدم والنجاح في المستقبل. ع. الاهتمام بالإعداد النفسي للطلاب واستخدام الاختبار ات النفسية كوسيلة موضو عية لتقويم حالة الطلبة.

$$
\text { المقترحات: في ضوء النتائج التي توصل لها البحث نقدم بعض المقترحات وهي: }
$$

ا. أجر اء در اسات ممائلة لعينات طلابية أخرى لاسيما مرحلة الابتدائية و المتوسطة والجامعة.

Y.دراسة القلق ألامتحاني و علاقة بالتحصيل الدراسي لاى طلبة الخامس الإعدادي ومر احل أخرى.

\section{المسادر العربية:}

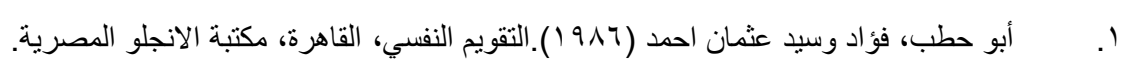

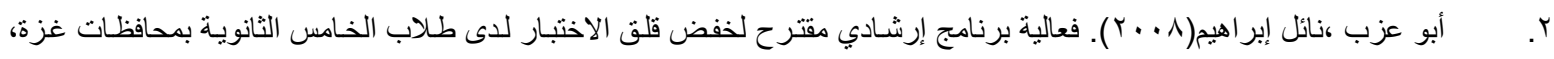

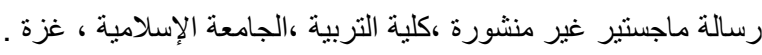

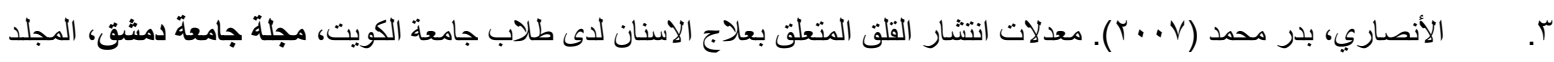

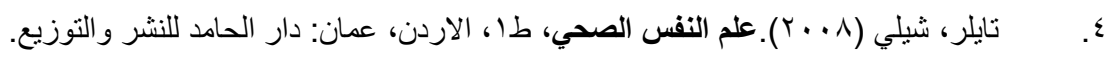

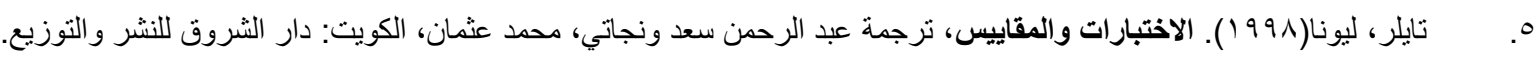




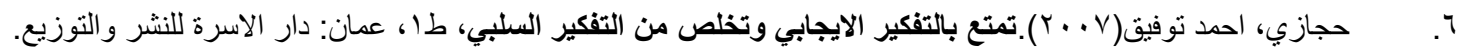

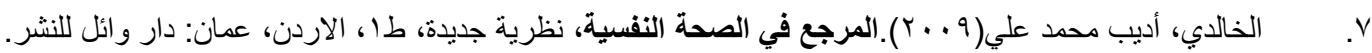

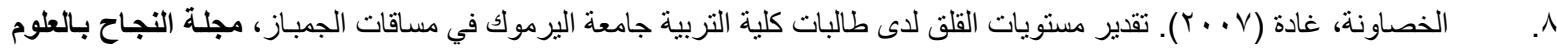

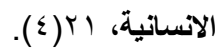

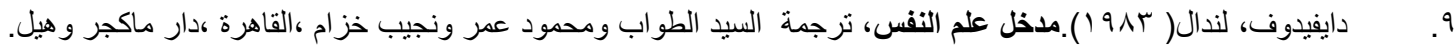

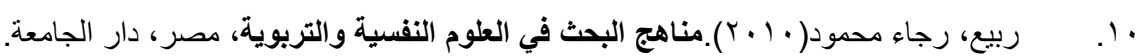

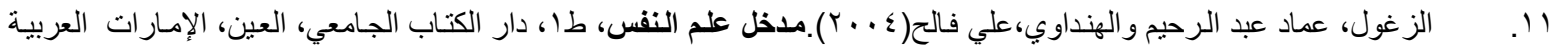

المتحدة.

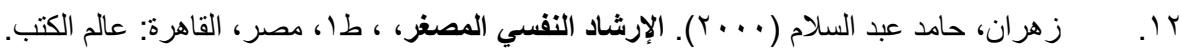

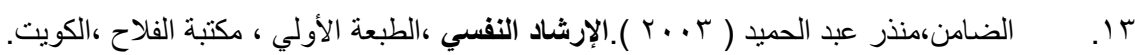

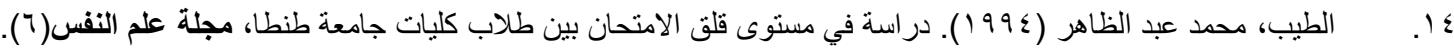

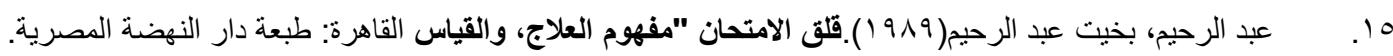

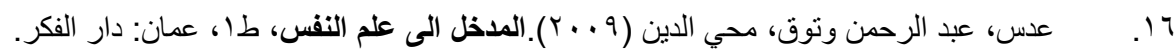

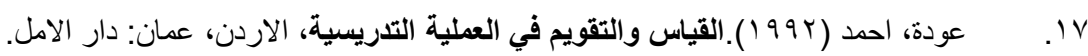

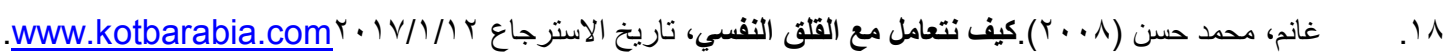

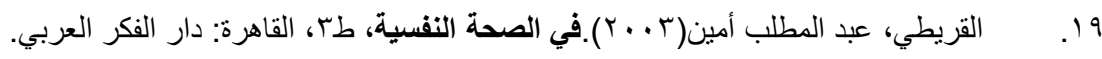

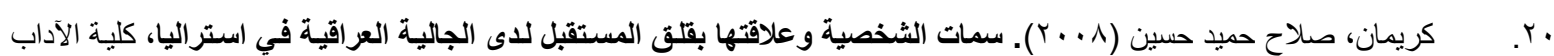
و التربية، الأكاديمية العربية المفتوحة في الدنمارك.

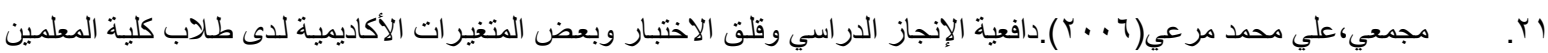

في جاز ان،رسالة ماجستير غير منشورة ،كلية التربية،جامعة أم القرى، مكة المكرمة.

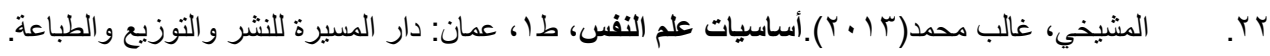

المصادر الاجنبية

rr. AIPy ، E. (r..r) To what extent do different explanations of pryudical suggest that it can be reduced.Journal of personality and social psychology، Vol. or ( $r$ r).

$r \varepsilon$. Chisell .E ( $19 \wedge \varepsilon)$ : Theorg of psychological measure ments، N Y.McGraw Hill.

ro. Cronbach T.M (। $९$ ) : Research in Development of Psgchology. the Free press -، New York.

r. Ebel، RI.( ( $9 \vee r)$ :Essentials of Educational Measurement New Jersey Hall Englewood. Clifes.

rv. Nokes، E (1991). Coping with Crises، London Royal College of Psychiatrists.

ץ^. Stanley. J Hokins. K. D( $(9 \vee r)$; Educational \&psgchological measurement\& EvAluation، Englewood Cliffs. N .G preutice.

ملحق رقم (1)

\begin{tabular}{|c|c|c|c|}
\hline مكان العمل & التخصص & اللقب والاسم & $ت$ \\
\hline جامعة سومرا كلية التربية الأساسية & علم النفس التربوي & أ.د عبد السجاد عبد بردان & -1 \\
\hline الجامعة المستنصرية اكلية التربية & علم النفس التربوي & أ.ـد لمياء ياسين الركابي & $-e^{-1}$ \\
\hline جامعة المستنصرية اكلية التربية & علم النفس التربوي & أ.د ابتسام سعدون محمد النوري & $-r$ \\
\hline جامعة ذي قار ا كلية التربية الإنسانية & صحة نفسية & أ.م.د عبد العباس غضيب الحجامي & $-\varepsilon$ \\
\hline جامعة سومر \ كلية التربية الأساسية & طرائق تدريس & أ.م.د حردان احمد حردان & -0 \\
\hline جامعة سومرا كلية التربية الأساسية & علم النفس التربوي & م.د اسراء عبد الحسين علي & -7 \\
\hline جامعة سومر \ كلية التربية الأساسية & علم النفس التربوي & م.د مشتاق خالد & $-V$ \\
\hline
\end{tabular}


جامعة سومر اكلية التربية الأساسية

مناهج بحث

م.د وسام حاتم زويد

$-\wedge$

جدول (•) مقياس التقلق الامتحاني بصيفته النهائية

\begin{tabular}{|c|c|c|c|c|c|c|}
\hline كبيرة & كبيرة & متوسطة & قليلة & قليلة جدا ق قار & 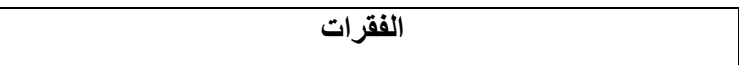 & $ت$ \\
\hline & & & & & أنشعر بالارتباك و التوتر عذد سماعي لكلمة امتحان & -1 \\
\hline & & & & & أشعر بالارتباك عندما يقترب موعد الامتحان . & $-r$ \\
\hline & & & & & ينتابني شعور بعدم الراحةٌ إثناء الامتحان . & $-\mu$ \\
\hline & & & & & أششعر بخيبة أمل قرب تقامي لامتحان مهم . & $-\varepsilon$ \\
\hline & & & & & أتوقع الفشل بعد تعرضي لاختبار ما . & -0 \\
\hline & & & & & أعاني من التوتر الثديد أثناء فترة الامتحانات . & -1 \\
\hline & & & & & أثشعر أن أدائي سوف يكون سيئا في الامتحان . & $-\mathrm{-V}$ \\
\hline & & & & & الخوف من الرسوب يعيق أدائي في الامتحان . & $-\wedge$ \\
\hline & & & & & أفكر في النتائج المترتبة علي رسوبي بالامتحان . & -9 \\
\hline & & & & & فترة الامتحانات هي من أصعب الأوقات لاي . & -1 . \\
\hline & & & & & أشُعر بسوء أدائي بالامتحانات رغم دراستي الجيدة له . & -11 \\
\hline & & & & & ينتابني الثكك في قلارتي على الإجابة عن بعض أسئلة الامتحان . & $-1 Y$ \\
\hline & & & & & أَتْور لأتفه الأسباب وقت الامتحانات . & -14 \\
\hline & & & & & أفقد السيطرة في التحكم بانفعالاتي وقت الامتحانات . & $-1 \leqslant$ \\
\hline & & & & & أثشعر بالعصبية الزائدة أثناء أدائي للامتحان . & -10 \\
\hline & & & & & أرفض المناقُشة مع الآخرين وقت الامتحانات . & -17 \\
\hline & & & & & أشُعر بالغضب الثديد إثناء أدائي للامتحانات . & $-1 V$ \\
\hline & & & & & تتسم تصرفاتي بالعدوانية وقت الامتحانات . & -11 \\
\hline & & & & & أفضل علم ممارسة بعض الأتشطة الاعتيادية وقت الامتحانات . & -19 \\
\hline & & & & & أنشعر بالحزن الثديد بعد أدائي للامتحانات . & $-r$. \\
\hline & & & & & أشثعر بالملل والاتزعاج الثديد أثناء فترة الامتحانات . & $-r \mid$ \\
\hline & & & & & أجد صعوبة في التوفيق بين متطلبات الأهل وتحقيق رغباتي في & -rr \\
\hline & & & & & أثنعر بالضيق والعجز عذ محاولتي تتفيذ ما يريده الأهل مني . & 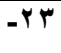 \\
\hline & & & & & أنشعر بعدم الرغبة في التحدث مع الآخرين وقت الامتحانات . & E \\
\hline & & & & & أرفض مقابلة الزائرين أثناء فترة الامتحانات . & 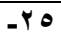 \\
\hline & & & & & أحب الجلوس بمفردي أثناء فترة الامتحانات . & -ז4 \\
\hline & & & & & أشتعر بفتور في علاقاتي الثخاتصية مع الزملاء أثناء فترة & $-r v$ \\
\hline & & & & & أفضل عدم المشاركة في المناسبات الاجتماعية أثناء الامتحانات & 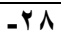 \\
\hline & & & & & أنثعر بالقلق من الجو المتوتر بالأسرة وقت الامتحاتات . & $-r q$ \\
\hline & & & & & أنشعر بالضيق الثديد للإلحاح المستمر من الوالدين على المذاكرة & $-r$. \\
\hline & & & & & أثشع بالضيق الثديد نتيجة الاهتمام الزائد بي من الو الاين أثناء & ו \\
\hline & & & & & أفتقل للجو الأسري المناسب والمثجع علي للاراسة والمذكرة . & -ret \\
\hline
\end{tabular}




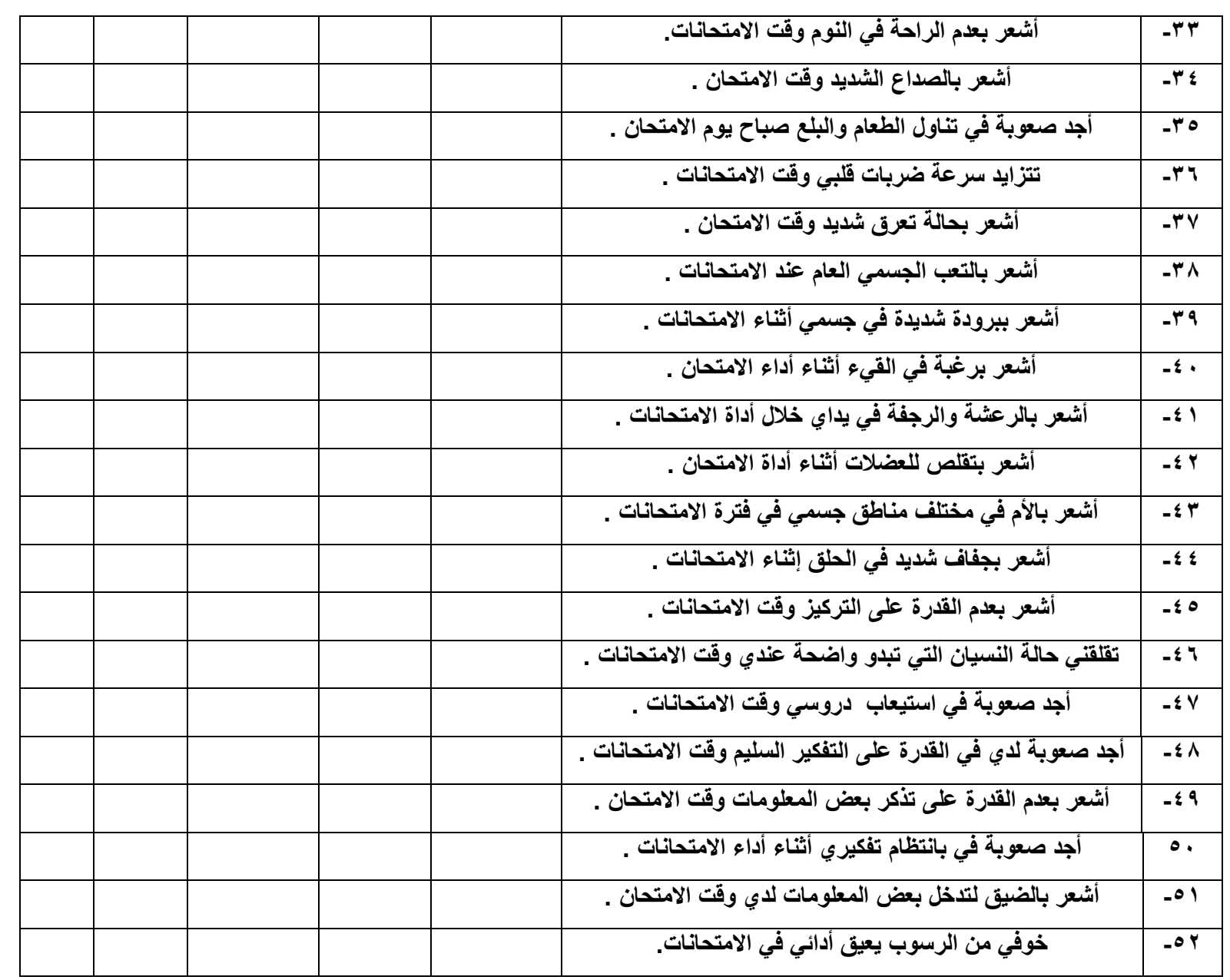

